\title{
Inštrumentálny realizmus ako možné východisko teoretickej reflexie vyučovania matematiky
}

\author{
Ladislav Kvasz \\ Univerzita Karlova, Pedagogická fakulta a Akademie věd ČR, Filosofický ústav
}

\begin{abstract}
Abstrakt: Cielom článku je predstavit' určitú epistemologickú pozíciu nazvanú inštrumentálny realizmus a ukázat', ako je možné ju využit' pri analýze rôznych prístupov k vyučovaniu matematiky. Inštrumentálny realizmus vychádza z presvedčenia, že úspešné poznávanie určitého výseku reality musí na jednej strane zohladnit' špecifický charakter výseku reality, ktorú poznávame, a na druhej strane musí zohladnit' epistemické nástroje, pomocou ktorých realitu poznáváme. (Rozdiel medzi termínmi epistemický a epistemologický je podobný ako medzi psychický a psychologický. Epistemický sa týka poznávania, epistemologický sa vzt’ahuje k filozofickej disciplíne, ktorá poznávanie skúma.) V prípade disciplín ako fyzika, biológia či psychológia uvedené dve požiadavky pravdepodobne nie sú kontroverzné. V prípade matematiky však hovorit’ o poznávanej realite a o nástrojoch, ktoré $\mathrm{k}$ tomu používame, už nie je úplne samozrejmé. Inštrumentálny realizmus tak otvára nový pohl'ad na poznávanie, ktorý, ako veríme, má celý rad dôsledkov pre vyučovanie matematiky.
\end{abstract}

Klúčové slová: inštrumentálny realizmus, didaktika matematiky, zmeny vedeckých teórií

\section{Instrumental Realism as a Possible Source of the Theoretical Reflection of Mathematics Education}

Abstract: The aim of the paper is to present an epistemological position called instrumental realism and to show how this position can be used as a tool for the analysis of different approaches to mathematics education. Instrumental realism is based on the conviction that any successful study of a particular segment of reality must on the one hand take into account the specific features of the particular segment of reality that we are studying. On the other hand, it must take into account the particular epistemic tools, by means of which we approach this segment of reality. In the case of physics, biology, or psychology, these two requirements do not seem controversial. Nevertheless, in the case of mathematics to speak about mathematical reality that we study or about the instruments that we use is much less obvious. Instrumental realism thus opens a new perspective on knowledge acquisition, that, as we believe, has many important consequences for mathematics education.

Keywords: instrumental realism, mathematics education, scientific change

V epistemológii, označovanej aj ako teória poznania, stoja proti sebe dva prúdy - realizmus, ktorý vychádza z predpokladu, že pri poznávaní poznávame niečo skutočné, čo je od nás do vel'kej miery nezávislé, a sme schopní dospiet' k poznaniu tejto skutočnosti; a konštruktivizmus, inšpirovaný hlavne filozofiou Immanuela Kanta, ktorý 
tvrdí, že skutočnost' ako taká je nám neprístupná a čo poznávame, sú naše mentálne konštrukcie. ${ }^{1}$ Inštrumentálny realizmus je realizmom $v$ tomto epistemologickom zmysle, teda predpokladá existenciu skutočnosti, ktorá je od nás nezávislá a ktorú poznávame. ${ }^{2}$ Od jednoduchého, priamočiareho realizmu sa však odlišuje tézou, že skutočnost' nám nie je daná bezprostredne, ale je prístupná iba sprostredkovane, pomocou nástrojov (vedeckých inštrumentov).

Inštrumentálny realizmus by som rád podrobnejšie predstavil v tomto článku. Jeho použitie pri riešení otázok filozofie matematiky som predviedol v knihe Inštrumentálny realizmus (Kvasz, 2015a). Kniha získala určitú odozvu aj medzi pedagógmi (Rusek, Slavík, \& Najvar, 2016; Slavík, 2017; Jirotková, 2017; Rodová \& Slavík, 2018; Kohout et al., 2019). To ma podnietilo pokúsit' sa inštrumentálny realizmus predstavit' spôsobom, zohl'adňujúcim záujmy a potreby pedagógov. Kniha (Kvasz, 2015a) vstupovala do filozofických diskusií, ktoré sú z pedagogického hladiska vedlajšie a prezentovala $z$ inštrumentálneho realizmu iba torzo, ktoré bolo z pohladu týchto diskusií relevantné. Časti inštrumentálneho realizmu som publikoval vo viacerých štúdiách a knihách, z ktorých nie je l'ahké zhromaždit' relevantné fragmenty a poskladat' ich do zrozumitel'ného celku. Práve o to sa chcem pokúsit' $v$ tejto štúdii. $\checkmark$ nasledujúcom texte budem preto často odkazovat' na vlastné práce (častejšie, než je $v$ bežnej štúdii únosné), aby som upozornil, kde možno nájst' určitú ideu podrobnejšie vysvetlenú a zasadenú do kontextu odbornej literatúry. V tejto štúdii sa budem výkladu detailov ako aj odkazom na odbornú literatúru skôr vyhýbat', aby bola prezentácia inštrumentálneho realizmu čo najkompaktnejšia a aby čitatel' čo najlahšie pochopil previazanost' jeho jednotlivých častí. Oboje, zdôvodnenie i kontext, môžu záujemcovia nájst’ v uvedených prácach.

\section{Východiská inštrumentálneho realizmu}

Inštrumentálny realizmus je omnoho širšia teória, než ako ho prezentuje kniha (Kvasz, 2015a). Vyrástol z kritiky sociologickej teórie vedeckých revolúcií, ktorú Thomas S. Kuhn predložil v knihe Štruktúra vedeckých revolúcií (Kuhn, 1982). Domnievam sa, že Kuhn vo svojej teórii zmiešal štyri kognitívne vel'mi rozdielne typy zmien a výsledná sociologická teória je dôsledkom tohto zmiešania. Môžeme si to predstavit', ako ked' na seba premietneme fotografie štyroch tvárí. Čo na výslednom obraze ostane, budú robustné črty, spoločné všetkým tváram, teda tmavé škvrny v oblasti očí a úst, svetlejšia plocha v oblasti čela a líc a celkový oválny tvar hlavy.

1 Je dôležité nestotožnit' epistemologický konštruktivizmus s didaktickým konštruktivizmom. Epistemologický konštruktivizmus je o tom, či je možné poznat' svet, didaktický konštruktivizmus je o tom, akým spôsobom si poznanie osvojujú deti. Autor tohto článku je epistemologický realista, ale pedagogický konštruktivista.

2 Podobne si nesmieme pomýlit' termín inštrumentálny, ktorý je súčast’ou spojenia inštrumentálny realizmus, s inštrumentalizmom, ako sa nazýva jedna antirealistická pozícia. Podla nej vedecké teórie nie sú opisy skutočnosti, ale sú to iba nástroje na predpovedanie javov. Teórie nie sú pravdivé či nepravdivé, ale vhodné, ak umožňujú robit' predpovede s požadovanou presnost'ou, a nevhodné, ak toho schopné nie sú. 
Detaily charakteristické pre jednotlivé tváre sa stratia. A presne to sa stalo Kuhnovi. Zmiešaním štyroch rôznych druhov kognitívnych dynamík stratil všetky detaily, ktoré sú charakteristické pre ten ktorý druh, a čo ostalo, je robustná štruktúra spoločná všetkým štyrom druhom, t. j. proces adaptácie vedeckého spoločenstva na zmenu. A tento proces opisuje Kuhnova teória. Prvá vec, ktorú musíme urobit' pred skúmaním procesu poznávania, je od seba oddelit' štyri druhy zmien. To je prvý krok na ceste $\mathrm{k}$ inštrumentálnemu realizmu.

\subsection{Klasifikácia vedeckých revolúcií}

V knihe $O$ revolúciách vo vede a ruptúrach $v$ jazyku vedy (Kvasz, 1998a) som sa pokúsil ukázat', že existujú štyri rôzne druhy zmien vo vede, alebo v Kuhnovej terminológii štyri rôzne druhy vedeckých revolúcií, ktoré nazývam idealizácia, re-prezentácia, objektácia a re-formulácia. Problematike klasifikácie vedeckých revolúcií sú venované práce (Kvasz, 1998a, 1999, 2012a, 2013a, 2014b). Predbežný, intuitívny obraz tejto klasifikácie je nasledovný.

Všetko poznanie pramení z nášho bezprostredného zmyslového kontaktu so skutočnost’ou, takže inštrumentálny realizmus sa hlási k empirizmu, pojatému dostatočne široko. ${ }^{3}$ Tento kontakt nás často poučuje, že veci sa majú inak, než sme si mysleli. $\mathrm{Na}$ jazyku vedy sa výsledok takéhoto kontaktu prejavuje $\mathrm{v}$ podobe re-formulácií. ${ }^{4}$ Re-formuláciou rozumieme minimálnu zmenu poznania. Príkladom re-formulácie, ktorú explicitne uvádza Kuhn ako vedeckú revolúciu, bol objav planéty Urán. Bola to nevratná zmena jazyka vedy, lebo po tomto objave už správna odpoved' na otázku, kol'ko je planét, vyzerá inak, ako pred týmto objavom. Re-formulácie sa na jazyku vedy prejavujú zavedením nového termínu (pre planétu Urán), ktoré však nevyžaduje zmenu pojmovej štruktúry, lebo astronómia poznala $v$ tej dobe už šest' planét a na ich opis mala osvedčený súbor pojmov.

Priamy zmyslový kontakt s poznávanou skutočnost’ou je často nestabilný. Psychológovia poznajú desiatky pokusov, ktoré to presvedčivo ilustrujú. Druhý typ zmien vo vede spočiva $v$ tom, že sa podarí zafixovat' situáciu poznávania a tým dochádza ku stabilizácii kontaktu so skutočnost’ou. Príkladom tejto zmeny je vznik perspektívy $\checkmark$ renesančnom maliarstve. Perspektíva sa zakladá na tom, že $v$ priestore nehybne zafixujeme hladisko, z ktorého je obraz konštruovaný. Síce sa nezmenil zmyslový kontakt a maliar aj nad'alej mal'uje to, čo vidí, a predsa môžeme z perspektivistického obrazu odčítat' obrovské množstvo detailov o priestorovom usporiadaní zobrazených postáv, ktoré z gotického obrazu odčítat' nemôžeme. Zmeny tohto typu nazývame objektácie, t. j. spredmetnenia, lebo hl'adisko, z pohladu ktorého je vytváraná reprezentácia, sa stáva bodom $v$ priestore, premieňa sa v objekt. Zmenou tohto druhu je aj kopernikovská revolúcia. Koperník sa ako prvý začal „pozerat““ na

3 Použili sme slovo „pramení“, čím chceme naznačit', že poznanie sa na zmyslový kontakt neredukuje.

4 Nevratnost’ou sa re-formulácia odlišuje od obyčajných reformulácií, pri ktorých sa môžeme vrátit’ spät'. 
10 slnečnú sústavu „zvonka“. V duchu si predstavil, že sa pozerá na človeka, ktorý je umiestnený na Zemi a pozoruje nočnú oblohu. Čo by taký pozorovatel', umiestnený na rotujúcej Zemi, uvidel, je presne to, čo vidíme my, teda že sa obloha otáča. A podobne Einstein si začal predstavovat', že sa nachádza vo vlaku letiacom rýchlostou svetla. Takéto zmeny, t. j. relativizácia hl'adiska, a následná stabilizácia zmyslového kontaktu so skutočnost’ou, sú z epistemologického hladiska vel'mi dôležité a zaujímavé. Je pravdepodobné, že problémy s priestorovou predstavivost'ou u žiakov sú spôsobené neschopnost'ou stabilizovat' prácu s priestorovými objektmi.

Ešte radikálnejšie než objektácie sú zmeny, pri ktorých sa bezprostredný, priamy, zmyslový kontakt so skutočnost'ou rozšíri, spresní a zjemní vd’aka zavedeniu inštrumentov. Inštrumenty často radikálnym spôsobom zvyšujú presnost' údajov, ktoré pomocou nich získavame. Zmyslový kontakt sa tým neruší, z inštrumentu musí niekto odčítat' dáta, ale otvára sa prístup $\mathrm{k}$ javom a rozlíšeniam, ktoré boli dovtedy často nepredstavitel'né. Nový inštrument spravidla neprichádza sám, ale v množstve variant a často prináša aj rad pomocných zariadení. Práca s inštrumentom si po čase vynúti zavedenie noriem a štandardných postupov, ako aj odlišenie správneho spôsobu narábania s inštrumentom od spôsobu nesprávneho. Zrodí sa nová inštrumentálna prax, ktorá prináša súbor zmien v spôsobe poznávania skutočnosti. Nová inštrumentálna prax spravidla umožňuje zaviest' celý rad nových rozlišení; upresňuje mnohé staršie pojmy a vynucuje si zavedenie pojmov nových. Okrem toho umožňuje odhalit' rad nových faktov a súvislostí. V tomto smere je asi najznámejším príkladom zavedenie d'alekohl'adu do astronómie, vd'aka ktorému došlo v priebehu roku 1610 $v$ astronómii $\mathrm{k}$ väčšiemu množstvu zásadných objavov, než za celé predchádzajúce storočie. Možno povedat', že nová inštrumentálna prax zakladá nový druh inštrumentálnej skúsenosti. Zmeny spočívajúce vo vzniku novej inštrumentálnej praxe nazývame re-prezentácie, lebo menia spôsob, ako je skutočnost' sprítomňovaná. Celé regióny javov, ktoré boli prv poznávaniu neprístupné, sa stávajú súčast’ou obrazu sveta. V matematike sú príkladom inštrumentálnej praxe konštrukcie pomocou kružidla a pravítka, ktoré umožňujú zásadným spôsobom zvýšit' presnost' geometrickej argumentácie, či symbolické odvodzovanie v rámci algebry, ktoré umožňuje nájst' riešenie radu problémov, ktorých riešenie si bez symbolického systému nevieme ani len predstavit' (napríklad rovnice tretieho stupňa).

Podobne, ako ku stabilizácii kontaktu so skutočnost’ou dochádza pomocou fixácie situácie, $v$ rámci ktorej poznávame skutočnost', tak existuje aj spôsob stabilizácie novej inštrumentálnej praxe. Zmena, ktorá niečo takého prináša, nazývame idealizácia, a spočíva vo vytvorení nového jazyka, teda nových pravidiel jeho syntaxe a sémantiky, ktorý umožňuje svet opisovat’ spôsobom, ktorý je v zhode s výsledkami inštrumentálnej praxe. Idealizácia je najradikálnejšou kognitívnou zmenou a jej lepšie približenie necháme na neskôr.

Druhý krok na ceste $\mathrm{k}$ inštrumentálnemu realizmu spočiva $v$ uvedomení si toho, že na každej zo štyroch úrovní prebieha poznávanie úplne inak. Re-formulácie sú lokálne zmeny terminológie, ale pre zvyšné tri druhy zmien je treba vypracovat' 
ich teóriu. Takže druhý krok cesty k inštrumentálnemu realizmu sa rozpadá na tri samostatné kroky, ktorým sú venované nasledujúce tri časti state.

\subsection{Objektácie a Wittgensteinova obrazová teória významu}

Vypracovaniu teórie objektácií sme venovali práce (Kvasz, 1996, 1998a, s. 108-149, 1998b, 2000b, 2001a, 2005a, 2006, 2008a, s. 107-224, 2020). Teória objektácií používa prvky obrazovej teórie významu z Wittgensteinovej knihy Tractatus Logico-Philosophicus (Wittgenstein, 1921/1989). Wittgenstein vytvoril obrazovú teóriu významu na vysvetlenie toho, ako sa jazyk vôbec môže vzt'ahovat' ku skutočnosti. Wittgensteinovo vysvetlenie je, že jazyk zobrazuje svet (preto obrazová teória významu), lebo svet a jazyk majú spoločnú formu zobrazenia. Hlavnou myšlienkou článku (Kvasz, 1996) bolo obrazovú teóriu významu použit’ na analýzu obrázkov v matematických textoch. Ukazuje sa, že ak obrazovú teóriu významu aplikujeme na geometrické obrázky, môžeme dejiny geometrie vyložit' ako striedanie rôznych foriem zobrazenia. ${ }^{5}$ Jednotlivé formy zobrazenia tak predstavujú rôzne spôsoby stabilizácie epistemického kontaktu so skutočnost'ou.

\subsection{Re-prezentácie a Fregeho chápanie symboliky}

Vypracovaniu teórie re-prezentácií sú venované práce (Kvasz, 1998a, s. 58-107, 2000a, 2008a, s. 11-106). Východiskom teórie re-prezentácií je opis dejín matematiky, ktorý predložil Gottlob Frege v článku Funkcia a pojem (Frege, 1891/1989). $\checkmark$ ňom Frege, jeden z tvorcov modernej logiky, rozdiely medzi aritmetikou a algebrou, respektíve medzi algebrou a kalkulom (diferenciálnym a integrálnym počtom) opisuje ako rozdiely v spôsobe vyjadrenia všeobecnosti. Stačilo Fregeho výklad doplnit' o výklad vývinu geometrie a získali sme opis logickej sily jazyka matematiky. Potom sme vo Fregeho duchu opísali vývin expresívnej, integratívnej a explanatorickej sily jazyka a výklad re-prezentácií v matematike bol hotový.

\subsection{Idealizácie a Husserlova teória idealizácie}

Vypracovaniu teórie idealizácií sú venované texty (Kvasz, 1998a, s. 32-57, 2002, 2003, 2005b, 2012b, 2013a, 2014a, 2017) a možno povedat', že dodnes nie je hotová. Kniha Paterns of Change, Linguistic Innovations in the Development of Classical Mathematis (Kvasz, 2008a) je zvláštna tým, že v nej chýba prvá kapitola. Pôvodný rukopis obsahoval ako prvú kapitolu výklad idealizácie vo fyzike. Čitatel' si to môže overit', ked' ju porovná so slovenskou verziou (Kvasz, 1998a), ktorej rozpracovaním a doplnením vznikol text anglickej knihy. Zistí, že kniha $O$ revolúciách vo vede a ruptúrach $\vee$ jazyku vedy obsahuje samostatnú kapitolu venovanú procesu ideali-

5 V tomto bode ideme nad rámec Wittgensteinovho Traktátu, ktorý predpokladal existenciu jediného jazyka (jazyka „vôbec“) a tak v jeho rámci myšlienka vývoja jazyka nedáva zmysel. Teda teória objektácií používa prvky obrazovej teórie významu (ale súčasne ide proti jej duchu). 
12 zácie vo fyzike (Kvasz, 1998a, s. 32-57). V roku 2008 som nedokázal opísat’ proces idealizácie $v$ matematike, a preto som namiesto neho chcel aj do anglickej knihy zaradit' opis idealizácie vo fyzike. Redaktor knihy, Donald Gillies, namietal, že zarad'ovat' do knihy venovanej filozofii matematiky pasáž o rozsahu vyše štyridsat' strán, venovanú fyzike, by mohlo odradit' prípadných čitatelov. Preto som prvú kapitolu z knihy vynechal a neskôr som ju rozšíril do podoby samostatnej knihy o idealizácii vo fyzike nazvanej Zrod vedy ako lingvistická udalost'. Galileo, Descartes a Newton ako tvorcovia jazyka fyziky (Kvasz, 2013a).

Práca na knihe venovanej opisu procesu idealizácie vo fyzike umožnila tomuto procesu hlbšie porozumiet', a toto porozumenie zúročit' pri analýze idealizácií $v$ matematike. Tak vznikli dva články venované procesu idealizácie v matematike. Už aj ich názvy Thalétova matematika v zrkadle Galileovej fyziky (Kvasz, 2014a) a Pythagorejská matematika vo svetle karteziánskej fyziky (Kvasz, 2017) naznačujú, že ako vodítko pri analýze idealizácie v matematike slúži opis idealizácie vo fyzike.

Princípy inštrumentálneho realizmu som sa snažil aplikovat' $v$ didaktike matematiky. Tak vznikli články (Kvasz, 2008b, 2013b, 2013c, 2015b, 2016, 2018).

\subsection{Inštrumentálny realizmus a iné teórie kognitívnych zmien}

Samozrejme, sústredením sa na výklad inštrumentálneho realizmu nechceme tvrdit', že neexistujú iné významné koncepcie, ktoré sa zaoberajú vzájomným vzt’ahom vývinu poznania v dejinách a u diet’at’a. Asi najznámejšou koncepciou tohto druhu je Piagetova genetická epistemológia, súhrnne predstavená v knihe Rolanda Garciu a Jeana Piageta Psychogenesis and the History of Science. Piagetova teória dodnes ovplyvňuje mnohých autorov. ${ }^{6} \mathrm{~V}$ tejto súvislosti môžeme spomenút' práce (Posner et al., 1982; Dubinsky \& Mcdonald, 2001; Hejný, 2007). Nechceme sa púšt'at' do kritiky renomovaných autorov ani opakovat' argumenty uvedené inde (Kvasz, 2001b). Chceme iba upozornit' na jednu výhodu historického prístupu, na ktorom je založený inštrumentálny realizmus, oproti koncepciám založeným na psychológii či didaktike. Tou výhodou je časový odstup. Zmeny, ktoré skúma Piaget a vedci inšpirovaní jeho prístupom, sú zmeny v reálnom čase, pričom všetky štyri druhy zmien, od re-formulácií až po idealizácie, sa odohrávajú súčasne. Naproti tomu pri historickom prístupe, na ktorom je založená naša klasifikácia zmien vo vede, skúmame historický vývoj určitej disciplíny, ktorý sa odohrával po dobu niekolkých tisícročí. Časový parameter umožňuje oddelit' zmeny jednotlivých druhov a vd'aka tomu dokážeme izolovat' jednotlivé druhy kognitívnych zmien. To prístupmi kognitívnej psychológie nie je možné dosiahnut'. Domnievame sa, že schopnost'ou vidiet' kognitívne javy $v$ ich čistote je

6 Aj jedna z mojich prvých publikácií v didaktiky matematiky (Kvasz, 1995) bola pokusom použit’ Piagetovu teóriu vo vyučovaní matematiky. Po čase som si uvedomil určité nedostatky Piagetovho prístupu a svoje kritické výhrady som zhrnul v polemickej stati (Kvasz, 2001b). Koncepciu inštrumentálneho realizmu možno chápat' aj ako pokus prekonat’ nedostatky Piagetovho prístupu. 
inštrumentálny realizmus špecifický a vd’aka nej môže prispiet' k rozvoju ostatných prístupov, tesnejšie zviazaných s psychológiou či didaktikou.

\section{Inštrumentálny realizmus a vyučovanie matematiky}

Vyučovanie matematiky je možné opísat' ako proces, pri ktorom sa v myslení žiaka snažíme navodit' určitý súbor kognitívnych zmien. V súlade so závermi kapitoly 1.1 budeme vychádzat' z hypotézy, že existujú štyri zásadne odlišné druhy kognitívnych zmien $v$ matematike. Jednotlivé druhy zmien sa od seba odlišujú mierou radikálnosti premien, ktoré v myslení žiaka vyvolávajú. Takéto premeny môžu siahat' od jednoduchého upresnenia terminológie, ked' sa žiak naučí rozlišovat' medzi blízkymi javmi, ako kružnica a kruh, ${ }^{7}$ obsah a obvod, či rovnost' a rovnica, až po pochopenie hlbokých matematických ideí, ako je napríklad idea duality, idea spojitosti, či idea linearity. V nasledujúcom texte sa pokúsime opísat' dôsledky každého zo štyroch druhov zmien pre didaktiku matematiky.

Aby sme štyri druhy kognitívnych zmien v matematike mohli l'ahšie odlišit', siahneme po príkladoch z histórie matematiky, na ktorých sú príslušné zmeny dostatočne jasne rozpoznatel'né. Ako východisko vezmeme Euklidove Základy, čo je jeden z najvýznamnejších matematických textov všetkých čias. Každý zo štyroch druhov kognitívnych zmien sa pokúsime ilustrovat' tým, že Euklidov text dáme do kontrastu s d’alším textom, ktorý sa od Základov odlišuje práve zmenou daného druhu.

Idealizácia je zmena, oddel'ujúca matematiku antického Grécka zameranú na dokazovanie tvrdení na základe definícií, postulátov a axióm, od viac menej empirickej matematiky starovekého Egypta a Mezopotámie, ktoré dôkaz nepoznali. Preto hovoríme, že matematika starovekého Egypta a Mezopotámie neprešla procesom idealizácie. Ako ilustráciu prvého druhu kognitívnych zmien preto možno vziat' protiklad Euklidove Základy verzus Rhindov papyrus.

Druhý druh zmien nazývame re-prezentácia. ${ }^{8}$ Je to zmena oddelujúca euklidovskú syntetickú geometriu od karteziánskej analytickej geometrie a hausdorffovskej fraktálnej geometrie. Prechod od syntetickej geometrie k analytickej geometrii spočíval v zmene spôsobu, ako reprezentujeme tvar, akým spôsobom vytvárame reprezentácie geometrických objektov. Ako ilustráciu druhého druhu kognitívnych zmien možno vziat' protiklad Euklidove Základy verzus Descartova La Géometrie.

Tretí druh zmien nazývame objektácia. ${ }^{9}$ Tento druh zmien ilustruje línia od Euklidových Základov, cez Desarguovu projektívnu geometriu, Bolyai-Lobačevského neeuklidovskú geometriu, Beltramiho model, až po Kleinov Erlangenský program. Za

7 Je zaujímavé, že Euklides medzi kružnicou a kruhom terminologicky nerozlišoval - oboje označoval slovom kyklos. Z kontextu bolo jasné, čo mal na mysli. Je preto otázne, či presnou terminológiou žiakov nemätieme, resp. či nerámujeme obraz, ktorý ešte nie je namal'ovaný.

8 V knihe Patterns of Change je termín re-prezentácia preložený ako re-coding, pozri s. 11-84.

9 V knihe Patterns of Change je termín objektácia preložený ako relativisation, pozri s. 107-159. 
14 ilustráciu tretieho druhu kognitívnych zmien možno preto vziat’ Euklidove Základy verzus Lobačevského 0 základoch geometrie.

Posledný druh zmien tvoria re-formulácie. Je to druh zmien, pri ktorých sa mení (a spresňuje) slovník, v ktorom sú poznatky formulované. Z množstva príkladov reformulácií uvedieme iba jeden, spojený s menom Johna Playfaira. Playfair bol vydavatelom Euklidových Základov v 18. storočí, ktorý dal piatemu postulátu podobu používanú dodnes. Ako kontrast ilustrujúci štvrtý druh kognitívnych zmien možno vziat' protiklad Euklidove Základy verzus Playfairovo vydanie Základov.

Musíme si uvedomit', že v histórii prebiehajú tieto štyri druhy zmien súčasne a sú rôzne prepletené. To isté platí aj o navodzovaní týchto zmien v mysli žiaka. Ale napriek tomu už aj uvedený prehl'ad stačí na to, aby sme si uvedomili, že je niečo zásadne odlišné žiakov naučit' analytickú geometriu (t. j. dosiahnut', aby v ich mysli prebehla určitá re-prezentácia), ako snažit' sa priviest' ich k pochopeniu toho, čo je to dôkaz (t. j. dosiahnut', aby $v$ ich mysli došlo k idealizácii tvaru).

\subsection{Idealizácia z pohl'adu didaktiky matematiky}

Väčšina matematikov, rovnako ako didaktikov matematiky úspešne prešla procesom idealizácie ešte $v$ detstve a preto si proces idealizácie vôbec neuvedomuje - ideálny charakter matematických objektov je pre nich samozrejmost'ou. Mnohí z nich majú dojem, že ideálne objekty matematiky, ako sú čśla, geometrické tvary či algebraické štruktúry, sa nachádzajú priamo $v$ realite. Ak určitý predmet má tvar, tak ho má $v$ matematickom zmysle tohto slova - ako dokonalú geometrickú formu. Ciel' vyučovania matematiky vidia $v$ tom žiakov naučit' tieto tvary pomenovat' a poznat' ich vlastnosti. Neuvedomujú si, že najradikálnejšou kognitívnou zmenou, ktorou diet'a pri učení sa matematike musí prejst', je naučit' sa tieto tvary kognitívne vyčlenit' a stabilizovat'. ${ }^{10}$ Táto zmena je námetom Platónovho podobenstva o jaskyni. ${ }^{11}$ Diet'a musí opustit' jaskyňu tieňov a naučit' sa vidiet' skutočné matematické predmety.

Edmund Husserl v jednom zo svojich posledných textov, vydanom až posmrtne s názvom Otázka o pôvode geometrie ako intencionálne-historický problém (Husserl, 1939) upozorňoval na nesamozrejmost' idealizácie. Význam idealizácie pre porozumenie matematiky opísal Petr Vopěnka v knihe Rozpravy s geometrií. Idealizáciu vyložil, v priamej nadväznosti na Husserlov text, ako schopnost' za reálnymi útvarmi uvidiet' ideálne geometrické objekty. Vopěnka to opisuje slovami:

Geometer má pred sebou list papiera pokreslený čiarami rozmanitých tvarov, rovnými aj krivými, navzájom poprepletanými a pretínajúcimi sa $v$ rôznych bodoch. Jeho zrak

10 Ked' tu tvrdím, že mnoho matematikov a didaktikov matematiky si proces idealizácie neuvedomuje, rovnako ako ked' budem tvrdit', že si neuvedomujú proces re-prezentácie, nemám na mysli všetkých matematikov. Verím, že existuje početná skupina matematikov, ktorí sa nad dejinami a didaktikou svojho oboru zamýšlajú. Ale súčasný stav vyučovania matematiky naznačuje, že hlas tejto skupiny nie je vo vyučovaní rozhodujúci.

11 Jaskyňa znázorňuje kognitívny svet predgréckej matematiky. 
spočinul na obrázku, jeho pohl'ad však prenikol cez obrázok, von z reálneho sveta do sveta geometrického. Tak napríklad za rovnou čiarou uvidel geometrickú úsečku, uvidel ju v jej úplnej čistote a spolu s ňou uvidel dokonalú priamost'. Od okamihu tohto prehliadnutia je pre neho navždy úsečka úsečkou geometrickou, a nie čiarou narysovanou podla pravítka.

Boli doby, kedy sme geometrický svet nepoznali. Deti, ktoré sa geometriu zatial' neučili, ho nepoznajú. Učitel' im tento svet otvorí. Jeho úloha je zdanlivo nesplnitel'ná, lebo tento svet nemôže ani ukázat', ani nenájde dostatok slov, ktorými by ho popísal. Môže ho iba rôzne navodzovat', napríklad narysovat' čiary pomocou pravítka a kružidla a povedat', že sa úsečkám a kružniciam podobajú, avšak ukázat' na nich môže len to, čím sa im nepodobajú. Do geometrického sveta môžeme niekoho viest' len na kus cesty, môžeme ho priviest' len pred jeho bránu, rozhodujúci krok však musí urobit’ každý sám. (Vopěnka, 2003, s. 23, preklad z češtiny L. K.)

Najdôležitejšou úlohou učitela pri vyučovaní matematiky je úloha, o ktorej píše Vopěnka. ${ }^{12}$ Otvorenie sa geometrického sveta je idealizácia, a z kognitívneho hladiska spočiva vo vytvorení epistemického prístupu k ideálnym geometrickým objektom. Je pozoruhodné, že v didakticko-matematickej literatúre sa proces idealizácie prakticky nespomína a zdá sa, že väčšina didaktikov matematiky si proces idealizácie ani neuvedomuje. ${ }^{13}$ Aby sme proces idealizácie pochopili, obrátime sa do histórie.

\subsubsection{Idealizácia vo fyzike}

Ako sme uviedli, kniha Patterns of Change výklad procesu idealizácie neobsahuje. Idealizácia sa v matematike odohrala medzi Thalétom (6. storočie p. n. l.) a Euklidom (3. storočie p. n. l.), teda v období, z ktorého takmer úplne chýbajú pôvodné pramene. Preto ked' chceme porozumiet' procesu idealizácie v matematike, nemáme inú možnost', než obrátit' sa k fyzike a následne matematický spôsob idealizácie rekonštruovat' na základe jeho paralely s fyzikálnym spôsobom idealizácie. Preto najprv na príklade fyziky opíšeme štádiá procesu idealizácie, a potom sa vrátime k matematike. Pomocou pojmov, ktoré zavedieme pri výklade idealizácie vo fyzike, budeme schopní opísat' základné etapy procesu idealizácie v matematike. V procese idealizácie vo fyzike je možné vyčlenit' tri etapy.

Prvú etapu tvorí galileovská fyzika, ktorá je z epistemologického hladiska pozoruhodná tým, že opisuje vždy iba pohyb jediného izolovaného telesa. Či už je to vol'ný pád, šikmý vrh, pohyb po naklonenej rovine alebo pohyb kyvadla, čo sú hlavné príklady systémov skúmaných Galileom, pohybuje sa vždy iba jedno teleso. Galileo akoby nebol schopný opísat' pohyb fyzikálneho systému zloženého z niekol'kých telies. Túto skutočnost' možno vyjadrit' slovami, že galileovskej fyzike chýba skladobná syntéza (nie je schopná spájat' telesá do fyzikálnych systémov). Podobne nikde v galileovskej fyzike nenájdeme opis interakcie medzi telesami, t. j. opis následkov pôsobenia jedného telesa na druhé. Preto galileovskej fyzike chýba deduktívna syntéza. Absen-

12 Husserl didaktický rozmer idealizácie nespomína, a v ňom tak možno vidiet' jeden z Vopěnkových postrehov.

13 Samozrejme tým nemyslíme, že by mali poznat' teóriu idealizácie - či už našu alebo hocakú inú. Idealizácia je však objektívne existujúca zmena a je prekvapujúce, ako málo didaktikov si túto zmenu uvedomuje, či už v histórii vedy alebo v psychike detí. 
16 cia skladobnej a deduktívnej syntézy je najzaujímavejšou epistemologickou črtou galileovskej fyziky. (Podrobne Kvasz, 2013a, s. 65-70.)

Druhú etapu procesu idealizácie vo fyzike predstavuje karteziánska fyzika. Descartes na rozdiel od Galilea udelil opisu interakcie medzi telesami centrálnu úlohu vo fyzikálnom obraze sveta. Na opis interakcie zaviedol základný model - model zrážky dvoch telies, podla ktorého sú všetky interakcie kontaktné a spočívajú v zrážke interagujúcich telies. Na opis kontaktných interakcií Descartes formuloval sériu pravidiel, ktorými sa interakcie riadia. Možno preto povedat', že Descartes prekonal základné nedostatky galileovskej fyziky - absenciu skladobnej a deduktívnej syntézy. Skladobná a deduktívna syntéza je však do karteziánskej fyziky zavedená pomocou konkrétneho modelu - pomocou modelu zrážky. Descartova fyzika tak predstavuje systém, v ktorom jeden konkrétny spôsob zjednotenia súboru telies do fyzikálneho systému a jeden konkrétny spôsob opisu interakcie medzi telesami bol prehlásený za univerzálny mechanizmus skladby a pôsobenia. Toto použitie konkrétneho modelu skladobnej a deduktívnej syntézy je pozoruhodnou kognitívnou črtou karteziánskej fyziky. (Podrobne Kvasz, 2013a, s. 106-123.)

Tretiu etapu procesu idealizácie vo fyzike predstavuje newtonovská fyzika. Newton nahradil Descartov opis kontaktnej interakcie telies pomocou modelu zrážky abstraktným opisom interakcie pomocou pôsobenia síl. Zrážka je špeciálnym prípadom interakcie pomocou pôsobenia síl, pri ktorom pôsobiace sily sú silami pevnosti a pružnosti materiálu. Možno preto povedat', že Newton oddelil skladobnú a deduktívnu syntézu od konkrétnych modelov, pomocou ktorých ich zaviedol Descartes. (Podrobne Kvasz, 2013a, s. 135-188).

\subsubsection{Idealizácia $v$ matematike}

Teóriu idealizácie vo fyzike chceme použit' pri analýze procesu idealizácie v matematike. Výsledkom je zatial' dvojica článkov Thalétova matematika v zrkadle Galileovej fyziky (Kvasz, 2014a) a Pythagorejská matematika vo svetle karteziánskej fyziky (Kvasz, 2017). Z ich nadpisov vidiet', že sa skutočne pokúšame preniest’ výklad idealizácie z fyziky na matematiku.

Thalétovská geometria vykazuje pozoruhodný stupeň podobnosti s galileovskou fyzikou. Je užitočné pozriet' sa na zoznam tvrdení, ktoré tradícia pripisuje Thalétovi. ${ }^{14}$ Nie je t’ažké si všimnút', že podobne ako boli jednoduché (t. j. nezložené) fyzikálne systémy, ktoré skúmal Galileo, aj Thalés opisoval iba jednoduché geometrické situácie. U Thaléta sa nestretneme s tým, čo bude základnou črtou euklidovskej geometrie - s geometrickou konštrukciou. Vety pripisované Thalétovi sa týkajú jednoduchých útvarov. Ked' konštrukciu pomocou pravítka a kružidla pochopíme ako skladobnú syntézu euklidovskej geometrie, tak môžeme povedat', že

14 T1: Priemer delí kruh na dve rovnaké časti. T2: Oproti zhodným stranám ležia v trojuholníku zhodné uhly. T3: Vrcholové uhly sú zhodné. T4: Trojuholníky, ktoré sa zhodujú v dvoch stranách a v uhle nimi zovretom, sú zhodné. T5: Určenie výšky pyramídy zmeraním d[̌žky jej tieňa vtedy, ked' má predmet rovnakú dĺžku ako jeho tieň. T6: Každý uhol nad priemerom je pravý. (Podrobnosti Kvasz, 2014a.) 
Thalétovej geometrii chýbala skladobná syntéza. Podobne, ked’ sa zamyslíme nad tým, ako asi Thalés svoje tvrdenia dokazoval, nie je t’ažké si uvedomit', že uvažované tvrdenia sa zakladajú na určitej symetrii. Ked' si túto symetriu uvedomíme, môžeme bezprostredne nahliadnut' pravdivost' tvrdenia. Možno preto povedat', že vety pripisované Thalétovi majú „jednokrokové“ dôkazy - pozrieme sa na obrázok, uvedomíme si jeho symetriu a nahliadneme pravdivost' vety. To ale znamená, že Thalétovej geometrii chýba deduktívna syntéza - teda ret’azenie argumentačných krokov dôkazu, ktoré sa opiera o explicitne sformulované axiómy.

Možno preto povedat', že Galileova fyzika a Thalétova geometria sa vyznačujú absenciou skladobnej syntézy (schopnosti opísat' fyzikálne systémy zložené z viacerých telies resp. geometrické útvary zložené z viacerých prvkov) a absenciou deduktívnej syntézy (schopnosti fyzikálne resp. geometrické fakty radit' do ret’azcov deduktívnych vzt'ahov). Galileova fyzika nebola schopná opísat', ako pôsobenie jedného telesa ovplyvní pohyb iného, rovnako ako Thalétova geometria nevedela opísat', ako sa vlastnosti jednej časti geometrickej konfigurácie odrazia na vlastnostiach inej.

Tak ako existuje epistemologická paralela medzi Galileovou fyzikou a Thalétovou geometriou, existuje podobná analógia medzi karteziánskou fyzikou a pythagorejskou matematikou. Pythagorejskú matematiku možno považovat' za odpoved' na hlavné nedostatky Thalétovej geometrie, podobne ako sme karteziánsku fyziku vyložili ako odpoved' na základné kognitívne nedostatky galileovskej fyziky (t. j. na absenciu skladobnej a deduktívnej syntézy). Pythagorejcom sa podarilo do matematiky zaviest' skladobnú a deduktívnu syntézu pomocou čísel. Čísla a ich pomery umožňujú dat' rôzne geometrické útvary do vzájomných vzt’ahov a výpočet opierajúci sa o číselné pomery umožňuje spájat' jednotlivé matematické propozície do ret’azca deduktívnej argumentácie. Ale ako sa ukázalo, pythagorejská matematika stála na vratkých základoch a stroskotala na objave nesúmeratel'nosti.

Články (Kvasz, 2014a, 2017) obsahujú rekonštrukciu prvých dvoch etáp procesu idealizácie v matematike. Ešte nás čaká rekonštrukcia tretej, euklidovskej etapy. Ale už aj tak vidíme, že základnou zmenou, ktorú proces idealizácie vnáša do matematiky, je zavedenie skladobnej a deduktívnej syntézy. Preto už aj predbežná a neúplná rekonštrukcia procesu idealizácie $v$ matematike umožňuje jasnejšie porozumiet' niektorým problémom didaktiky matematiky, a predovšetkým naznačuje cestu, po ktorej môže žiak vstúpit' do geometrického sveta, o ktorom píše Vopěnka.

\subsection{Re-prezentácie z pohl'adu didaktiky matematiky}

Matematika existovala v minulosti vo vel'mi odlišných podobách. Napríklad v algebre sa po dobu šest'sto rokov nepoužívali symboly a algebraické úpravy mali podobu úprav súvetí bežného jazyka. Historici toto štádium vývinu algebry nazývajú rétorická algebra. Po rétorickej algebre nastúpilo asi dvesto ročné obdobie synkopickej algebry, kedy sa pre termíny, označujúce rôzne mocniny neznámej a operácie s nimi, zaviedli skratky tvorené prvými písmenami zodpovedajúceho slova latinského jazyka. Nakoniec okolo roku 1590 sa zrodila algebra ako ju poznáme dnes - symbolická 
18 algebra. Ani tento typ zmien si matematici často neuvedomujú a algebraické objekty stotožňujú s ich symbolickou reprezentáciou. Pre dnešného matematika je algebraický vzt’ah takmer automaticky symbolickým vzt’ahom. Medzi jeho verbálnou a symbolickou formuláciou nevidí zásadný rozdiel - symbolický zápis je o niečo stručnejší a presnejší než verbálna formulácia, ale hovorí to isté.

Každý žiak žije kognitívne $v$ určitom matematickom univerze - pozná jeho určité typické objekty, niekol'ko nevšedných a prípadne záhadných objektov. Okrem univerza geometrických útvarov patrí do matematického univerza aj svet aritmetických objektov (z ktorých napríklad číslo m niektorých žiakov do tej miery fascinuje, že sú schopní naučit' sa spamäti aj sto jeho cifier) a svet symbolických objektov (ako sú rovnice, polynómy a pod.). Preto druhá úloha, ktorá stojí pred učitelom matematiky po tom, ako sa žiakovi podarilo mentálne vstúpit' do sveta ideálnych objektov, je žiaka previest' z univerza syntetickej geometrie do univerza analytických kriviek, rovnako ako ho previest' z aritmetického univerza čísel do symbolického univerza algebry.

Z pohladu kognitívnej vedy nevieme, ako prechod z jedného univerza ideálnych objektov do druhého takéhoto univerza vyzerá. Nevieme, ako vyzerá kognitívny svet žiaka, ktorý sa nachádza niekde na pól ceste medzi univerzom euklidovskej syntetickej geometrie a univerzom kartézskej analytickej geometrie. Spočiatku asi ku starému univerzu pridá niekol'ko nových objektov, ale nakoniec sa musí novým objektom prispôsobit' celá kognitívna siet'. Pokusom opísat' tento proces prostriedkami kognitívnej vedy je kniha Paula Thagarda Conceptual Revolutions (Thagard, 1992). Tu niet miesta na opis procesu re-prezentácií v dejinách matematiky (pozri Kvasz, 2008a, s. 11-105). Obmedzíme sa na opis vzniku jedinej re-prezentácie - na vznik symbolickej algebry.

\subsubsection{Vznik symbolickej algebry ako príklad re-prezentácie}

Mnohí matematici ani didaktici matematiky si neuvedomujú zdíhavý proces, ktorý viedol ku vzniku určitej reprezentácie. ${ }^{15}$ Jednotlivé matematické javy, objekty a vzt’ahy chápu tak, ako ich opisujeme pomocou dnešného, plne rozvinutého matematického jazyka. Výuka matematiky založená na používaní jej súčasného jazyka však neumožňuje žiakom prejst' procesom re-prezentácie, ktorý viedol ku vzniku tohto jazyka. Žiaci si tak nemôžu uvedomit', čo je na danej reprezentácii konvenciou, teda vecou dohovoru, a čo je faktom, teda skutočnost'ou od ludských konvencií nezávislou. Aby sme si uvedomili komplexnost' zmien ktoré re-prezentáciu sprevádzajú, opišeme cestu, ktorú prešla algebra, kým vznikla dnešná symbolika.

15 Re-prezentáciou (písanou s pomlčkou) rozumieme proces zmeny, kým reprezentáciou (bez pomlčky) rozumieme výsledok tohto procesu. Teda príkladom reprezentácie je jeden zo systémov geometrie: syntetická, analytická či fraktálna; re-prezentáciou je napríklad prechod od syntetickej geometrie $k$ analytickej. 


\section{A) Rétorická algebra (800-1600) ${ }^{16}$}

Historici matematiky kladú vznik algebry ako samostatnej disciplíny do deviateho storočia a spájajú ho s arabským matematikom Muhammadom Al-Chwárizmím. Al-Chwárizmí v Krátkej knihe o počte algebry a al-muqábaly (Al-Chwárizmí, po $800 / 1983)$, prv ako sa pustil do riešenia určitej úlohy, jej „rovnicu“ previedol na tvar, $v$ ktorom boli iba kladné koeficienty a pri najvyššej mocnine bola jednotka. ${ }^{17}$ Aby

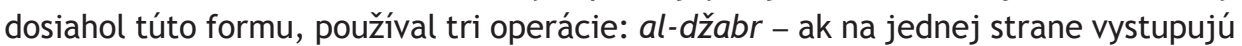
členy, ktoré treba ubrat', tak sa k obom stranám pripočíta zodpovedajúca hodnota; al-muqábala - ak vystupujú na oboch stranách rovnaké mocniny, odčíta sa menší člen na jednej strane od väčšieho na druhej; al-rad - ak je koeficient pri najvyššej mocnine rôzny od jednotky, tak sa ním vydelí celá „rovnica“. Názov al-džabr v názve knihy sa začal používat' na označenie náuky o rovniciach.

Al-Chwárizmího postup si ukážeme na úprave, ktorá v našej symbolike vyzerá nasledovne:

$21 \frac{2}{3} x-2 \frac{1}{6} x^{2}=100+2 x^{2}-20 x$ al-džabr

$100+4 \frac{1}{6} x^{2}=41 \frac{2}{3} x$.

Al-Chwárizmí píše:

... to bude dvadsat' jedna vecí a dve tretiny veci bez dvoch majetkov a jednej šestiny, rovné sto a dvom majetkom bez dvadsiatich vecí. „Al-džabruj to“, a pridaj dva majetky a jednu šestinu k sto a dvom majetkom bez dvadsiatich vecí, a pridaj tých od sta a dvoch majetkov ubratých dvadsat' vecí k dvadsat' jednej veci a dvom tretinám veci. Tak si dostal sto a štyri majetky a šestinu majetku rovné štyridsat' jednej veci a dvom tretinám veci.

Na tomto postupe je pozoruhodný verbálny spôsob zápisu „rovníc“ - „rovnica“ je rozsiahla veta arabského jazyka. Al-Chwárizmí síce nepoužíva symboliku, ale napriek tomu „rovnice“ upravuje a rieši. Používa pritom príkazy ako „al-džabruj to“, t. j. operácie, ktorých predmetom nie sú čísla, ale „algebraické termy“. ${ }^{18}$

Aby nevznikol dojem, že výsledky, ktoré možno dosiahnut’ prostriedkami rétorickej algebry, sú triviálne, uvedieme riešenie rovnice tretieho stupňa z Cardanovej

16 Ako rétorickú by bolo možné označit' aj vel'kú čast' matematiky starého Egypta a Mezopotámie (s výnimkou tabuliek a čisto numerických fragmentov). Algebra sa však vyznačuje tým, že $v$ jej rámci sa manipuluje (počíta, upravuje) aj s niečím iným než s číslami. Typickým príkladom je operácia al-džabr, ktorá zodpovedá náśmu preneseniu výrazu na druhú stranu rovnice. Tu sa manipuluje s termom algebraického jazyka a nie s číselným výrazom. Preto vznik rétorickej algebry je vhodné klást' na začiatok deviateho storočia.

17 Slovo rovnica dávame do úvodzoviek, lebo Al-Chwárizmí nepoužíval symboly a algebraický vzt’ah, ktorý riešil, zapisoval vetou arabského jazyka obohateného o niekol'ko technických termínov.

18 Ked’ sme úryvok Al-Chwárizmího textu prepísali do našej symboliky, vidíme tiež, že pri úprave „prehodil strany rovnice“. V prvom súvetí stojí slovo sto (tj. absolútny člen rovnice) za slovom rovné, v poslednom stojí pred týmto slovom. 
20 knihy Ars Magna sive de regulis algebracis (Cardano, 1545/1968). Rovnicu Cardano zapisuje: „De cubo et rebus aequalibus numero“ (tretia mocnina a veci sa rovnajú číslu). Jej riešenie uvádza $v$ tvare pravidla:

Umocni na tretiu jednu tretinu počtu vecí, pridaj k tomu štvorec polovice čísla rovnice a vypočítaj druhú odmocninu z tohto celku. Toto zduplikuj, a k jednej z dvoch pridaj polovicu čísla rovnice a od druhej odčítaj polovicu toho istého. Potom budeš mat' binomium a jeho apotome. Potom odčítaj tretiu odmocninu apotome od tretej odmocniny binomia, zvyšok, ktorý ostane, je vec (Cardano 1545/1968, s. 98).

Teda žiaden vzorec, žiadna formula, ale pravidlo (t. j. regula), tak ako slubuje názov knihy „de regulis algebracis“. Aby sme pochopili, čo Cardano robí, je užitočné jeho verbálny text prepísat' do dnešnej symboliky, čím dostaneme tzv. Cardanov vzorec (Cardano takýto vzorec nikdy nenapísal):

$$
x=\sqrt[3]{\frac{c}{2}+\sqrt{\left(\frac{c}{2}\right)^{2}+\left(\frac{b}{3}\right)^{3}}}-\sqrt[3]{-\frac{c}{2}+\sqrt{\left(\frac{c}{2}\right)^{2}+\left(\frac{b}{3}\right)^{3}}}
$$

Vidíme, že rétorická algebra rozhodne nebolo krátke či nezaujímavé obdobie dejín algebry. Práve naopak, trvalo takmer osemsto rokov a obohatilo algebru o významné matematické výsledky.

\section{B) Synkopická algebra (1400-1600)}

Aj ked' Cardano hlavný matematický výsledok svojej knihy - postup riešenia rovnice tretieho stupňa - vyjadril prostriedkami rétorickej algebry, nebola to rétorická algebra, ktorej prostriedkami bol tento výsledok dosiahnutý. Aspoň dve storočia pred Cardanom existovala paralelne s rétorickou algebrou, ktorá algebraické problémy zapisovala prostriedkami bežného jazyka obohateného o niekol'ko technických termínov, aj synkopická algebra. Synkopická algebra používala systém skratiek, ked' technické termíny jazyka algebry nahradzovala ich prvými písmenami.

Ako prvú ilustráciu synkopickej algebry uvedieme príklad pochádzajúci od Regiomontana. Ten roku 1463 pri zápise rovnice, ktorú by sme $v$ dnešnej symbolike zapísali v tvare

$$
250 x-25 x^{2}=2 x^{2}+100-20 x,
$$

použil prvky synkopickej algebry a príslušnú rovnicu zapísal ako:

$250^{\mathrm{r}}$ ig $25^{\mathrm{c}}-2^{\mathrm{c}}$ et 100 ig $20^{\mathrm{r}}$.

Neznámu označoval písmenom $r$ od latinského res (vec), jej druhú mocninu písmenom $c$ od latinského census (sčítanie ludu, odhad majetku, lebo majetok mal podobu pôdy, teda obsahu). Neznámu písal ako horný index, čo je princíp, ktorý používame na označenie mocniny neznámej dodnes. Dlhšia vodorovná čiara zobra- 
zujúca rovnováhu na dvojramennej váhe znázorňuje rovnost'. Náš symbol pre rovnost’ vznikol, ked’ sa dve ramená váhy „oddelili“ a „umiestnili“ pod seba. Používaním špeciálneho znaku pre rovnost’ a používaním pravého horného indexu na označenie neznámych Regiomontanus prekračuje medze synkopickej algebry. Jeho označenie mocnín neznámej prvými písmenami slov res a census je však charakteristickým znakom synkopickej algebry.

Johannes Widmann vydal roku 1489 učebnicu Behende und hübsche Rechnung auf allen Kaufmanschaft (Rýchle a pekné počítanie pre každého kupca), v ktorej sprehl'adnil zápis mocnín neznámej v synkopickej algebre až po deviatu mocninu: $r$ (res - vec); z (zensus - majetok, využívajúc nemeckú vokalizáciu); c (cubus - kocka); a pre vyššie mocniny zz; rzz; zzz; czz; zzzz; czzz. Synkopickú algebru používal aj Cardano. Pravidlo na riešenie rovnice tretieho stupňa síce vyjadril prostriedkami rétorickej algebry, pri jeho odvodení však pravdepodobne použil prostriedky synkopickej algebry.

Rozhodujúci krok odvodenia Cardanovho pravidla bol predpoklad, že riešenie je rozdielom dvoch neznámych. A práve zavedenie označenia druhej neznámej bolo jednou z hlavných inovácií synkopickej algebry. Použivali sa na to rôzne triky: písmená označujúce mocniny prvej neznámej sa brali z latinských termínov, kým pre druhú neznámu sa používali písmená odvodené z termínov niektorého z miestnych jazykov; inokedy sa písmená označujúce mocniny prvej a druhej neznámej písali rôznou farbou, alebo sa používali vel'ké a malé písmená. Táto inovácia bola pre riešenie rovníc tretieho stupňa rozhodujúca (pozri Kvasz, 2008a, s. 167-172).

Cardano riešenie rovnice tretieho stupňa ilustroval na príklade rovnice $x^{3}+6 x=20$ (cubus a šest' vecí je rovný dvadsat'). Jej riešenie zapísal prostriedkami synkopickej algebry v tvare:

$R V: c u b: R: 108$ p: $10 \mathrm{~m}: R V: c u b: R: 108 \mathrm{~m}: 10$,

Tu $R V^{19}$ je z radix universalis (teda odmocnina určitého výrazu na rozdiel od obyčajnej odmocniny čísla, označovanej $R$ ). Skratka cub je od cubica, a znamená, že $R V$ je tretia odmocnina. Písmená $p$ a $m$ označujú $v$ súlade $s$ princípom synkopickej algebry operácie plus a mínus.

19 Latinská abeceda mala pôvodne iba 21 písmen. Písmená U a V, rovnako ako I a J sa začali dôsledne rozlišovat' až od 17 . storočia. $\mathrm{V} 16$. storočí sa universalis skracovalo ako V. 
C) Symbolická algebra (1600-1830 n. l. $)^{20}$

Synkopická algebra sa síce na prvý pohlad iba mierne odlišuje od rétorickej algebry, ale napriek tomu predstavovala významný technický pokrok. Jej prostriedkami bolo objavené pravidlo na riešenie rovnice tretieho stupňa. Napriek tomuto nespochybnitel'nému úspechu obdobie synkopickej algebry trvalo iba 200 rokov a následne bola synkopická algebra vytlačená symbolickou algebrou. Odstránenie synkopickej algebry malo dobré dôvody.

Priame naviazanie algebraických znakov označujúcich mocniny $(r, z, c)$ a operácie $(R, p, m)$ na zodpovedajúce termíny (res, zensus, cubus, radix, plus, mínus) má nespochybnitel'nú výhodu - príslušné znaky sa l'ahko pamätajú. Táto výhoda je však vykúpená radom nedostatkov. Prvým z nich je skutočnost', že symbolika synkopickej algebry nedrží identitu neznámej, čo je problém napríklad pri substitúcii. Ked' za $r$ dosadíme $r+2$, tak sa automaticky zmenia hodnoty aj ostatných mocnín, ale znaky $z$ a $c$ to nenaznačujú. Medzi znakmi $r, z, c$ neexistuje žiaden súvis, podobný tomu, ktorý na symboloch $x, x^{2}$ a $x^{3}$ ukazuje, že ak za $x$ dosadíme $x+2$, tak namiesto $x^{2}$ budem mat' $(x+2)^{2}$. Ďalší nedostatok sa týka umocňovania a odmocňovania. V synkopickej algebre medzi označením operácií umocňovania a odmocňovania nie je súvislost', takže skladanie týchto operácií je neprehladné. Ako tretí nedostatok synkopickej algebry môžeme uviest' nesystematické riešenie problému druhej neznámej, ktoré robí zavedenie tretej neznámej prakticky nemožným. Preto už v rámci synkopickej algebry vznikali zárodky inovácií, ktoré vyústili u Vièta a Descarta do vzniku symbolickej algebry.

Vznik symbolickej algebry budeme ilustrovat' na zavedení a ustálení rôznych aspektov jediného symbolu - symbolu pre odmocninu. Odmocňovanie je, rovnako ako umocňovanie, operáciou pochádzajúcou $z$ aritmetiky. $V$ algebre sa $z$ odmocniny stala základná operácia, používaná pri riešení rovníc.

Regiomontanus zaviedol okolo roku 1460 do matematiky odmocniny a vypracoval pravidlá na počítanie s nimi. Aritmetickú operáciu odmocňovania, t. j. kalkulatívny proces, premenil na algebraický výraz - odmocninu. Odmocninu označoval velkým písmenom $R$ z latinského radix (koreň), takže $\sqrt{8}$ písal ako $R$ de 8 a $\sqrt[3]{7}$ ako $R$ cubica de 7. Prechod od procesu $k$ objektu sa tak odohral už $v$ rámci synkopickej algebry (čo je jej d’alší významný prínos).

Nicolas Chuquet používal na označenie odmocniny písmeno $R$, podobne ako Regiomontanus. Stupeň odmocniny však nevypisoval slovne, ale pomocou horného číselného indexu, takže napríklad jeho $R^{2} 30$ znamenalo $\sqrt{30}$. Pozoruhodným aspektom Chuquetovej symboliky bolo, že na označenie rozsahu odmocňovania používal podčiarkovanie, takže tvrdil, že $R^{2} 14 p R^{2} 180$ egaulx $3 \tilde{p} R^{2} 5$, čo $v$ našej symbolike znamená $\sqrt{14+\sqrt{180}}=3+\sqrt{5}$. Luca Pacioli v Summa de arithmetica z roku 1494 naproti tomu na označenie rozsahu odmocňovania písal pred členy, ktoré chcel odmocnit', písmeno $V$ od universale (spoločný). Teda $R V 35 \widetilde{m} R 50$ znamenalo $\sqrt{35-\sqrt{50}}$.

20 Rok 1830 odkazuje k nástupu štrukturálnej algebry, ktorej priekopníkom bol Evariste Galois. V súčasnosti máme dočinenia s nástupom d’alšieho - kategoriálneho štádia. 
Michael Stifel roku 1544 v knihe Arithmetica integra (Úplná aritmetika) prehodil malé $r$ a vel'ké $R$ pri značení neznámej a odmocniny. Odmocninu označoval štylizo-

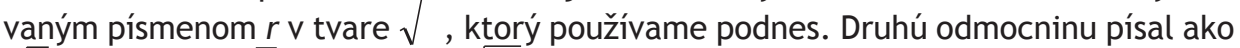
$\sqrt{z}$, tretiu ako $\sqrt{c}$, štvrtú ako $\sqrt{z z}$.

René Descartes je tvorcom našej symboliky pre odmocniny a zaviedol ju $v$ knihe Geometria, vydanej v roku 1637. Od Stifela prijal ideu vziat' štylizované malé $r$ ako symbol pre odmocninu. To, že o ktorú odmocninu ide, vyjadril pomocou aritmetického indexu podobne ako Chuquet. Tým sa vyprázdnilo miesto pod odmocninou, kam Stifel písal označenie stupňa (teda z pre druhú odmocninu či zz pre štvrtú), a Descartes tam mohol umiestnit' argument, teda odmocňovaný výraz. Descartes prijíma aj Chuquetovu myšlienku, že rozsah odmocniny je vyznačený pomocou vodorovnej čiary (fungujúcej ako určitý druh zátvoriek). Na rozdiel od Chuqueta však použil hornú čiaru, čo umožnilo spojit' ju s hornou nožičkou znaku pre odmocninu $r$, a náš symbol pre odmocninu je na svete.

Na tomto stručnom prehl'ade ${ }^{21}$ zmien, ktoré spoločne vytvárajú symbol pre odmocninu, je pozoruhodné, že prakticky žiaden aspekt symbolu pre odmocninu sa nezrodil v podobe, v akej bol do výsledného symbolu začlenený. Ked' zdĺhavú cestu, ktorá v histórii matematiky viedla ku vzniku symbolickej algebry, porovnáme s tým, ako sa algebra vyučuje na základnej a strednej škole, môžeme si uvedomit' dve veci. V dejinách matematiky etape symbolickej algebry predchádzalo dlhé obdobie rétorickej a synkopickej algebry. Školská prax tieto dve štádiá vynecháva a žiakom predkladá algebru hned' v jej symbolickej podobe. Potom nás nesmie prekvapit', že deti nevedia algebraické symboly spojit' s realitou. Druhou vecou, ktorú si môžeme uvedomit', je skutočnost', že aj samotné vytvorenie algebraickej symboliky bol zložitý a zdĺhavý proces. Školská prax tento proces redukuje na zavedenie výsledného symbolu. Je otázne, či ked’ žiakom ponúkneme až výsledný produkt, je vôbec možné, aby plne pochopili pravidlá, ktorými sa použitie týchto symbolov riadi.

\subsection{Objektácie z pohl'adu didaktiky matematiky}

Objektácie - alebo spredmetnenia - sú tretím druhom kognitívnych zmien v matematike. Podobne ako v predchádzajúcich prípadoch, aj v prípade objektácií si ich ukážeme najprv na príklade z histórie matematiky a potom sa pozrieme aké majú miesto vo vyučovaní matematiky.

\subsubsection{Objektácie $v$ dejinách algebry}

$\mathrm{Na}$ chvíl'ku sa vrátime ku Cardanovmu pravidlu pre riešenie rovnice tretieho stupňa a pozastavíme sa u dvoch termínov, ktoré Cardano použil - binomium a apotome. Binomium je $\frac{c}{2}+\sqrt{\left(\frac{c}{2}\right)^{2}+\left(\frac{b}{3}\right)^{3}}$ a jeho apotome je $-\frac{c}{2}+\sqrt{\left(\frac{c}{2}\right)^{2}+\left(\frac{b}{3}\right)^{3}}$. Sú to prav-

21 Podrobnejší opis týchto zmien sme kvôli tomu, aby nerušil súvislé plynutie textu, umiestnili do dodatku na konci textu. 
24 depodobne prvé technické termíny označujúce zložené termy jazyka algebry. Použitie týchto termínov je dokladom kognitívnej zmeny, ktorú označujeme termínom objektácia či spredmetnenie. Cardano tu odkazuje ku dvom algebraickým výrazom. Robí to však bez použitia symboliky. To ukazuje, že ku spredmetneniu dochádza pred nástupom algebraickej symboliky. Spredmetnenie je kognitívna zmena, pri ktorej z určitého procesu sa stáva objekt (preto objektácia). To, či pre príslušný objekt nájdeme vhodné symbolické vyjadrenie (napríklad to, ktoré sme použili ako symbolický prepis Cardanových slov), je vedlajšie. Ide o schopnost' určitý kognitívny obsah vyčlenit', osamostatnit', udržat' vo vedomí a rôzne s ním manipulovat'. Takže u Cardana sa rodí kognitívny prístup k algebraickým výrazom ako k novému druhu algebraickej skutočnosti.

Ked' si uvedomíme, že matematika nie je prírodná veda, teda predmety svojho výskumu nenachádza v prírode, ale prakticky všetky matematické objekty sa zrodili (alebo aspoň kognitívny prístup k nim vznikol) v procese spredmetnenia, vidíme, ako zásadnú úlohu hrá proces postupného spredmetňovania pre rozvoj matematiky. Tento proces sme podrobne popísali v knihe Patterns of Change a nebudeme sa tu púšt’at' do jeho výkladu. Uvedieme iba záverečný prehlad jednotlivých štádií objektácií v algebre (Kvasz, 2008a, s. 198-200). Vo vývine algebry možno rozlíšit' aspoň sedem štádií, ktoré sa líšia $v$ tom, čo znamená riešit' algebraickú rovnicu. Riešit' rovnicu $g(x)=0 \vee$ rôznych vývinových štádiách algebry znamená:

a) Nájst' regulu, teda pravidlo zapísané v bežnom jazyku, ktoré vyjadruje návod ako vypočítat' koreň rovnice. Príkladom je Cardanovo riešenie rovnice tretieho stupňa, uvedené v kapitole 2.2.1.

b) Nájst' formulu, teda výraz symbolického jazyka algebry, ktorý umožňuje vyjadrit' koreň rovnice pomocou jej koeficientov, štyroch aritmetických operácií a odmocňovania. Jednotlivé znaky formuly zodpovedajú krokom výpočtu, takže formula je symbolickým zápisom reguly.

c) Nájst' rozklad formy, teda polynóm zodpovedajúci rovnici rozložit' na súčin lineárnych členov. Každý člen rozkladu formy obsahuje výraz vyjadrujúcu jeden koreň, takže rozklad formy dáva tol'ko koreňov, kolkého stupňa je rovnica. Riešit' algebraickú rovnicu na tomto, rovnako ako na nasledujúcich štádiách, znamená pre rovnicu $n$-tého stupňa nájst' všetkých jej $n$ koreňov.

d) Nájst' rezolventu, teda daný problém previest' pomocou substitúcie na pomocnú úlohu nižšieho stupňa. Ked' vyriešime pomocnú rovnicu, spätnou substitúciou dostávame riešenie pôvodného problému. Okrem koreňov rovnice dostávame aj čísla s nimi asociované. Teda v prípade rovnice $n$-tého stupňa dostaneme vo všeobecnosti $n$ ! veličín. $Z$ pomedzi nich možno vybrat' $n$, pomocou ktorých sa dá príslušná forma rozložit' na lineárne členy.

e) Nájst' rozkladové pole $Q\left(\alpha_{1}, \ldots \alpha_{n}\right)$ obsahujúce všetky korene polynómu. Kroky konštrukcie rozkladového pola priamo zodpovedajú príslušným rezolventám.

f) Nájst' faktorizáciu grupy symetrií pol'a $Q\left(\alpha_{1}, \ldots \alpha_{n}\right)$, teda grupu symetrií rozložit' pomocou systému normálnych podgrúp. Faktorizácia grupy korešponduje rozkladu 
pol’a na jednotlivé rozšírenia, a tak zo znalosti faktorizácie grupy možno usudzo-

vat' na konštrukciu rozkladového pol'a.

g) Vytvorit' faktorizáciu okruhu Q[x] podla ideálu $(g(x))$, teda nájst' triedy rozkladu okruhu polynómov podla ideálu prislúchajúceho danému polynómu. Jedna z tried je hladaným riešením rovnice, a tak máme univerzálny postup na riešenie l'ubovol'nej algebraickej rovnice.

Ak sa čitatel' ešte nestretol s niektorými pojmami použitými v bodoch a) až g), to nie je podstatné. Uvedený zoznam sme uviedli iba kvôli tomu, aby sme ilustrovali postupnost' abstrakčných zdvihov, ku ktorým v dejinách algebry došlo. Samozrejme, nie všetky uvedené úrovne tvoria náplň učiva základnej alebo strednej školy. Spolu však vhodne ilustrujú bohatstvo a rôznorodost' pojmotvorného procesu v algebre. Ked' si podobnú postupnost' predstavíme okrem algebry aj v aritmetike, syntetickej geometrii a analytickej geometrii, získame aspoň približnú predstavu o bohatstve a zložitosti pojmovej výstavby matematiky. Aj ked' sa žiak z mnohými z týchto pojmov nestretne, ostáva ich stále dostatočné množstvo na to, aby dali didaktikom podnet na zamyslenie.

\subsection{Re-formulácie z pohl'adu didaktiky matematiky}

Nahradenie jednej formulácie (určitého tvrdenia, definície, argumentu) iným, presnejším, jasnejším alebo stručnejším (teda neekvivalentným) vyjadrením nazývame re-formuláciou. Na rozdiel od idealizácií či re-prezentácií si matematici aj didaktici matematiky re-formulácie dobre uvedomujú. Na matematike je nápadná presnost' jej jazyka a mnohí učitelia vidia svoju úlohu v tom naučit' žiakov presným, jasným a stručným formuláciám matematických poznatkov. Žiakom tieto presné, jasné a stručné formulácie predvedú, potom ich precvičujú a následne skúšajú, ako sa ich žiaci naučili.

To, čo konštruktivisti označujú ako tzv. transmisívna metóda vyučovania matematiky, to z kognitívneho hl'adiska možno vymedzit' ako vyučovanie, založené na presvedčení, že žiakov možno matematiku naučit' postupnost'ou re-formulácií. 22 Tzv. transmisívna metóda je konštruktivistami kritizovaná preto, lebo ignoruje zákonitosti pojmotvorného procesu, nevytvára v mysli žiaka základné pojmy, ale odovzdáva mu iba presné formulácie hotových poznatkov. Zástancovia tzv. transmisívnej metódy sa podla konštruktivistov uspokoja, ked' žiak vie zopakovat' presné formulácie preberaných definícií, poznatkov a postupov riešenia štandardných úloh.

Z matematického hl'adiska sú niektoré re-formulácie zaujímavé. Ako príklad uvedieme re-formuláciu piateho postulátu, ktorý Euklides formuloval slovami:

22 Termín transmisívna metóda používame s prívlastkom „tzv.“, aby sme zvýraznili, že to je termín, ktorý používajú konštruktivisti na označenie svojich oponentov. Didaktici, ktorých výuku konštruktivisti takto nazývajú, však sami seba takto neoznačujú, lebo toto označenie nepovažujú za adekvátne ani presné. 
A ak nejaké dve priame čiary pretne iná priama čiara tak, že vytvorí na jednej strane vnútorné uhly menšie než dva pravé, tak aby sa tieto priame čiary, ak budú predížené do nekonečna, stretli na tej strane, na ktorej sú uhly menšie než dva pravé (Šír, ed., 2011, s. 117, preklad z češtiny L. K.).

Táto formulácia piateho postulátu má $v$ gréckom origináli 36 slov. Zvyšné štyri postuláty majú dohromady iba 32 slov. V roku 1795 anglický matematik John Playfair uverejnil text Euklidových Základov, v ktorom Euklidovu formuláciu nahradil novou:

Ak je daná priamka l a bod $P$, ktorý na nej neleží, môžeme viest' jednu a len jednu priamku prechádzajúcu bodom $P$, ktorá nepretne l (Gray, 1989, s. 87). ${ }^{23}$

Obe formulácie piateho postulátu sú z logického hladiska ekvivalentné, z prvej vyplýva druhá a naopak. Ale z kognitívneho hladiska je medzi nimi rozdiel. Playfairova formulácia otvára dvere smerom k neeuklidovským geometriám. Stačí spojenie „jednu a len jednu“ nahradit’ slovom „dve“ alebo „žiadnu“ a máme Bolyaiov-Lobačevského resp. Riemannov systém neeuklidovskej geometrie.

Príklad piateho postulátu ukazuje, že problematika re-formulácií je významná, zaujímavá a kognitívne dôležitá. Ked' konštruktivisti kritizujú prístup k vyučovaniu matematiky, ktorý výuku zakladá na tom, že žiakom predkladá presné formulácie hotových poznatkov, to neznamená, že by snaha o presnost' pri formulovaní matematických poznatkov nebola dôležitá. Tzv. transmisívna metóda nie je zlá kvôli tomu, čo robí, ale kvôli tomu čo nerobí. Spravidla totiž žiakom nepomáha pri procesoch objektácií, re-prezentácií a predovšetkým idealizácie. Kvôli tomu je konštruktivistami kritizovaná. To, že poznatky, ktorých presné formulácie žiakom predkladá k pamät'ovému učeniu, sú pekné, užitočné a dôležité, o tom nik nepochybuje. Ale aj keby sa ich žiaci dokonale naučili, matematiku sa tak nenaučia. Budú ju schopní nanajvýš imitovat'.

\section{Záver}

Celkovo možno povedat', že zmeny v pojatí matematiky, ktoré si väčšina z nás nie vždy uvedomuje, ako sú idealizácie, re-prezentácie a aj niektoré objektácie, ${ }^{24}$ sú

23 Tvrdenie ekvivalentné s Playfairovou formuláciou uvádza Euklides ako vetu XXXI prvej knihy Základov a formuluje ho slovami „Daným bodom ved' rovnobežku s danou úsečkou“. Keby toto tvrdenie povýšil na postulát, sloveso by musel zmenit' z imperatívu (ved') na neurčitok (viest'), rovnako ako je to u Playfaira. Samozrejme, vol'ba iného tvrdenia za piaty postulát nie je jediná vec, $v$ ktorej sa Euklidov pôvodný systém odlišuje od Playfairovho. Liśia sa tým, že Euklides pracuje výhradne s konečnými objektmi, kým Playfair pracuje s nekonečnými priamkami (čo je objektácia, ktorú sme podrobnejšie vyložili v knihe Kvasz, 2008a). Jej zvláštnost’ou bolo, že sa primárne odohrala $v$ maliarstve, nie v geometrii (pozri Kvasz, 2020, s. 22-48). Ale ked' si túto zásadnejšiu zmenu odmyslíme, stále tu je možnost' vybrat' vetu XXXI za piaty postulát. Euklides to mohol urobit', ale neurobil to. Playfaira uvádzame ako doklad toho, že sa to urobit' dá, a keby to bol Euklides urobil, dejiny geometrie by sa pravdepodobne uberali úplne inými cestami. Problematiku piateho postulátu podrobnejšie analyzuje napríklad Vincenzo De Risi (2016).

24 Ako bol prechod od konečných úsečiek k nekonečným priamkam $v$ renesancii. 
vel'mi zložité zmeny. Inštrumentálny realizmus je schopný rôzne druhy kognitívnych zmien detailne popísat', a tak môže didaktike matematiky ponúknut' nástroje na analýzu týchto zmien $v$ poznávacom procese $u$ žiaka, kedy sú jednotlivé druhy zmien vzájomne prepletené a rôzne sa prekrývajú, ked’že prebiehajú všetky súčasne. Okrem toho môže inštrumentálny realizmus ponúknut' didaktike matematiky aj určité základné poznatky o dynamike jednotlivých druhov zmien.

Asi najvýznamnejší prínos inštrumentálneho realizmu však vidíme $v$ celkovom prístupe k vyučovaniu matematiky. Inštrumentálny realizmus ponúka určitú alternatívu, či tretiu cestu, medzi pojatím didaktiky zameraným na učivo, ktoré vidí ciel' vzdelávania v odovzdaní určitého súboru poznatkov (či určitého kultúrneho dedičstva), a pojatím didaktiky zameranej na kompetencie, ktoré vidí ciel' vzdelávania v naučení schopnosti prakticky konat' v určitých situáciách. Prvý z týchto prístupov je bližší humanitným oborom, predovšetkým histórii a literatúre, kde sa kladie väčší dôraz na to mladej generácii odovzdat' dedičstvo, ktoré sme dostali od našich otcov a matiek, v jeho komplexnosti a bohatstve. Naproti tomu kompetencie viac vyhovujú potrebám výuky cudzích jazykov, kde je dôležité naučit' žiaka cudzí jazyk predovšetkým aktívne používat', kým kultúrne reálie, viažuce sa k danému jazyku, stoja až v druhom pláne. Matematika sa nachádza niekde medzi týmito dvomi krajnost’ami. Inštrumentálny realizmus, upriamením pozornosti na postupnost' kognitívnych zmien v mysli žiaka, ponúka tretie pojatie zmyslu vyučovania: cielom vyučovania je navodit' v mysli žiaka kognitívne zmeny, ktoré sú predpokladom úspešného porozumenia a aktívneho osvojenia si učiva.

Tento prístup akceptuje, že zmyslom vyučovania je odovzdat' určité dedičstvo, ale týmto dedičstvom je kognitívne dedičstvo, teda schopnost' rozumiet', objavovat' a riešit' problémy. Matematika je nositel'kou tisícročnej tradície počítania, dokazovania a konštruovania, a toto dedičstvo sa dá odovzdat' len ako porozumenie jeho pravidlám počítania, porozumenie jeho argumentom pri dokazovaní a porozumenie jeho postupom konštruovania. Na druhej strane prístup inštrumentálneho realizmu akceptuje, že žiakov musíme naučit' matematiku aktívne používat' v reálnych situáciách. Ale $v$ matematike, na rozdiel od jazyka, neexistujú kompetencie (pre zdôvodnenie tejto tézy pozri Kvasz, 2016, s. 36-41). To, čo učíme, nie je zvládanie situácií, ale vhl'ad do nich, porozumenie príčinám toho, prečo to, čo robíme, aj skutočne funguje. Hovorca jazyka nemusí vediet' zdôvodnit' gramatické pravidlá, ktorými sa pri používaní jazyka riadi - väčšina z nás si všetky pravidlá gramatiky ani neuvedomuje. A určite po ňom nechceme, aby pravidlá gramatiky zovšeobecňoval. Naproti tomu v matematike pokial' nerozumieme tomu, prečo veci fungujú, vlastne nerobíme matematiku, ale len imitujeme prácu tých, ktorí matematike rozumejú. ${ }^{25}$ Ked' v matematike niečo pochopíme, je prirodzené skúsit' to zovšeobecnit', vyskúšat' to $v$ iných kontextoch.

25 Učenie sa jazyka je práve takýto imitatívny nácvik. V čom sa matematika zásadne odlišuje od jazyka a prečo v matematike neexistujú kompetencie, je práve to, že matematika nie je založená na imitácii, ale na porozumení. Matematiku nie je možné sa naučit' (myslí sa naučit' sa naspamät'), ale je možné ju iba pochopit'. 
V kapitole 2.2.1. sme stručne ilustrovali vznik symbolickej algebry na príklade vzniku a ustálení rôznych aspektov jediného symbolu - symbolu pre odmocninu. Odmocňovanie je, podobne ako umocňovanie, operácia známa $z$ aritmetiky. $V$ algebre však dochádza k premene odmocňovania na odmocninu, ktorú môžeme aplikovat' nielen na čísla, ale aj na algebraické výrazy.

Ako sme spomenuli, bol to Regiomontanus kto zaviedol do matematiky pojem odmocniny a vypracoval pravidlá na počítanie s odmocninami. Odmocninu označil vel'kým písmenom $R$, takže $\sqrt{8}$ písal ako $R$ de 8 a $\sqrt[3]{7}$ ako $R$ cubica de 7 .

Nicolas Chuquet už nevypisoval stupeň odmocniny slovne, ako Regiomontanus, ale pomocou horného číselného indexu, takže napríklad jeho $R^{2} 30$ znamenalo $\sqrt{30}$. Táto inovácia má štyri aspekty. Po prvé symbol pre odmocninu sa stáva zloženým symbolom. Skladá sa z časti označujúcej identitu operácie $R$ (tá ešte nesie stopy synkopickej algebry; $R$ odkazuje na radix) a indexu 2 označujúceho jej stupeň. Po druhé, index udávajúci stupeň je aritmetickým indexom, takže automaticky kóduje vzt’ahy rôznych odmocnín pri operáciách - napríklad, že tretia odmocnina z druhej odmocniny je šiesta odmocnina (teda umocňovanie a odmocňovanie vedie $k$ násobeniu indexov), čo je prvý krok na ceste $\mathrm{k}$ logaritmom. Po tretie aritmetický index umožňuje zaviest' záporné odmocniny, čo Chuquet aj skutočne urobil. Niečo také v aritmetike, kde umocňovanie znamená opakované násobenie, nedáva zmysel. Naše $42 x^{2}: 6 x^{5}=7 x^{-3}$ zapísal ako $42^{2} \div 6^{5}$ egaulx $7^{3 \widetilde{m}}$. Tu $\widetilde{m}$ je synkopický znak, ktorý označuje mínus. Štvrtým aspektom Chuquetovej symboliky pre odmocniny bolo, že na označenie rozsahu operácie odmocňovania používal podčiarkovanie.

Luca Pacioli písal pred členy, ktoré chcel odmocnit', písmeno $V$ od universale (spoločný). Teda $R V 35 \widetilde{m} R 50$ znamenalo $\sqrt{35-\sqrt{50}}$. Myšlienka označit' rozsah operácie odmocňovania sa tak objavila nezávisle $v$ niekol'kých variantoch. Aj ked' Pacioliho spôsob nie je tak dobrý ako Chuquetov, Cardano pri zápise riešenia rovnice tretieho stupňa použil Pacioliho zápis. Ked' Cardanovu formulu RV: cub: R: 108 p: $10 \mathrm{~m}: R V$ : cub: $R: 108 \mathrm{~m}: 10$, prepíšeme do našej symboliky, ktorá kopíruje Chuquetove používanie vodorovnej čiary na označenie rozsahu odmocniny, len miesto podčiarkovania my výraz, ktorý sa má odmocnit', „nadčiarkujeme“, dostaneme $\sqrt[3]{\sqrt{108}+10}-\sqrt[3]{\sqrt{108}-10}$. Porovnaním oboch zápisov vidíme nejednoznačnost' symbolu $R V$ a tým aj výhody Chuquetovho podčiarkovania. Napriek tomu bola Pacioliho symbolika dostatočne flexibilná, aby Cardanovi umožnila vyjadrit' riešenie rovnice tretieho stupňa. Súčasne tu vidíme jeden z motívov, poháňajúcich vývin algebraickej symboliky, totiž snahu po jednoznačnosti symbolov.

Michael Stifel neznámu označoval vel'kým $R$, aby mohol malé $r$ použit' na označenie odmocniny. Teda iba prehodil malé $r$ a vel'ké $R$ pri značení neznámej (res) a odmocniny (radix). Odmocňovanie označoval štylizovaným písmenom $r v$ tvare $\sqrt{\text {, }}$ ktorý používame podnes. Toto je pozoruhodný prechod od synkopickej algebry k symbolickej, kde v Stifelovom znaku prestávame cítit' jeho synkopický pôvod (malé $r$ ) a začíname ho vnímat' ako čistý symbol (t. j. konvenčne zvolený znak bez akého- 
kolvek súvisu s tým, čo označuje). Druhú odmocninu písal ako $\sqrt{z}$, tretiu ako $\sqrt{c}$,

štvrtú ako $\sqrt{z}$. Teda aj Stifel chápal symbol pre odmocninu ako zložený z dvoch komponent, a prináša tretiu komponentu. Vedla prvej komponenty, ktorou je štylizované $r$ slúžiace ako indikátor identity (Chuquet identitu odmocniny označoval vel'kým $R$ ), a druhej komponenty, ktorou je indikátor stupňa odmocniny (kde ešte nepoužíva aritmetický index, ale synkopický znak ako z, c, či zz) Stifel vyčleňuje miesto pod znakom odmocniny, z ktorého sa vyvinie miesto pre argument. Ešte toto miesto nepoužíva na umiestnenie argumentu, t. j. odmocňovaného výrazu. Miesto toho tam dáva indikátor stupňa. Ale rozhodujúce je, že Stifel rozpoznal možnost' vnorit' do symbolu pre odmocninu d'alšie znaky.

René Descartes je tvorcom našej symboliky pre odmocniny. Od Stifela prijal ideu vziat' štylizované malé $r$ ako symbol pre odmocňovanie. To, že o ktorú odmocninu ide, vyjadril pomocou aritmetického indikátora (podobne ako Chuquet), a nie pomocou písmena ako Stifel. Tomuto indikátoru dal podobu l'avého horného indexu (Chuquet používal pravý horný index) a pripojil ho ku znaku pre odmocninu (kam ho píšeme podnes). Tým sa vyprázdnilo miesto pod odmocninou, kam Stifel umiestňoval indikátor stupňa. Descartes tam mohol umiestnit' argument, teda odmocňovaný výraz, čím vytvoril asi po prvý krát v dejinách odlišenie funkcionálneho symbolu a argumentu. Descartes okrem toho prijíma Chuquetovu myšlienku, že rozsah odmocniny je vyznačený pomocou vodorovnej čiary (fungujúcej ako určitý druh zátvoriek). Na rozdiel od Chuqueta však použil hornú čiaru a nie dolnú, čo umožnilo spojit' ju s hornou nožičkou štylizovaného $r$ označujúceho identitu odmocniny do jediného znaku.

Môžeme zhrnút': symbol pre odmocninu vznikol zrastením viacerých aspektov: ${ }^{26}$

1. Zavedenie indikátora identity odmocniny pomocou synkopického znaku $R$ od slova radix (1460 - Regiomontanus)

2. Zavedenie indikátora stupňa odmocniny pomocou synkopického znaku alebo celého slova, na označenie toho, o ktorú odmocninu ide (1460 - Regiomontanus)

3. Zavedenie indikátora rozsahu pôsobenia odmocniny pomocou symbolického znaku v tvare vodorovnej čiary (podčiarknutia) ako istého typu zátvoriek (1484 - Chuquet)

4. Premena indikátora stupňa zo samostatne stojaceho synkopického znaku na pravý horný aritmetický index (1484 - Chuquet).

5. Premena indikátora stupňa zo samostatne stojaceho synkopického znaku na pravý horný aritmetický index (1484 - Chuquet). ${ }^{27}$

6. Nahradenie synkopického označenia identity odmocniny pomocou vel'kého $R$ malým r, ktoré sa dá spojit' s d’alšími prvkami zloženého znaku (1544 - Stifel).

26 V prehl'ade aspektov výsledného symbolu pre odmocninu a ich zmien sme sa usilovali odlišit' zavedenie, t. j. vznik nového aspektu, ktorý v pôvodnej alebo $v$ pozmenenej podobe bude trvalou súčast’ou symbolu; premenu, čím rozumieme konceptuálny zdvih zvyšujúci expresivitu symbolu alebo jeho jednoznačnost'; nahradenie, čím rozumieme zmenu, ktorá modifikuje pôvodný nápad niečím, čo je s ním $v$ zásade rovnocenné, ale lepšie ladí s ostatnými prvkami; a zrastanie, čím rozumieme spojenie jednotlivých aspektov do výsledného symbolu.

27 Body 4 a 5 označujú rôzne aspekty jednej veci. Na Chuquetovom indikátore stupňa odmocniny je zaujímavé jednak, že ide o index, ktorý by však mohol byt' aj synkopický, a jednak to, že tento index je aritmetický. 
30 7. Zavedenie miesta pre indikátor stupňa odmocniny ako prázdneho miesta vloženého pod znak odmocniny (1544 - Stifel).

8. Nahradenie pravého horného indexu ako indikátora stupňa odmocniny l'avým horným indexom (1637 - Descartes).

9. Nahradenie podčiarkovania ako indikátora rozsahu pôsobenia odmocniny hornou čiarou (1637 - Descartes).

10. Premena miesta pod znakom odmocniny z miesta pre indikátor stupňa odmocniny na miesto pre argument (1637 - Descartes).

11. Zrastenie miesta pre argument (10), hornej čiary (9), l'avého horného indexu (8) $v$ tvare aritmetického indexu (5) so štylizovaným malým $r$ (6) v jediný symbol, na ktorom nevidno švy medzi jeho uvedenými aspektmi (1637 - Descartes).

Uvedený zoznam jedenástich zmien, ktoré vytvárajú symbol pre odmocninu, má dve zaujímavé črty. Jednak si môžeme všimnút', že inovácie neprichádzajú jednotlivo, ale v určitých zhlukoch (od Regiomontana sú dve, od Chuqueta tri, od Stifela dve a od Descarta tri), teda ako keby existovali určité fragmentárne riešenia, ktoré umožnia zvládnut' určitý aspekt výslednej symboliky. Okrem toho prakticky žiaden aspekt symbolu pre odmocninu sa nezrodil $v$ podobe, $v$ akej bol do výsledného symbolu začlenený, teda výsledná symbolika je výsledkom kompromisov medzi jednotlivými fragmentmi. To jasne ukazuje kognitívnu zložitost' vzniku symbolickej algebry.

Samozrejme, nebolo by vhodné, keby sa škola usilovala kopírovat' všetky zákruty cesty vedúcej ku vzniku algebraickej symboliky od Regiomontana po Descarta. Ale ani súčasná prax, ktorá žiakom predkladá až výsledný produkt $v$ jeho monolitickej (teda jednotnej a uhladenej) podobe, sa nezdá byt' najvhodnejšou. Svedčia o tom okrem iného aj notoricky známe t’ažkosti žiakov so slovnými úlohami (teda úlohami rétorickej podoby, ktoré žiaci nevedia preložit' do symbolického zápisu). Je možné, že okrem vynechania synkopickej algebry, ktorá je prirodzeným mostom medzi rétorickou a symbolickou algebrou, tu svoju úlohu hrá aj to, že jednotlivé aspekty algebraickej symboliky (ako sú indikátor stupňa, indikátor identity, indikátor rozsahu, a odlišenie funkcionálneho symbolu a argumentu) prichádzajú všetky naraz. Vyššie uvedených jedenást' bodov a predovšetkým odlišenie jednotlivých indikátorov predstavujú pokus rozbit' algebraickú symboliku na jej kognitívne komponenty, ktoré môžu slúžit' ako východisko pre vypracovanie didaktického postupu pre ich zavedenie. ${ }^{28}$

\section{Pod'akovanie}

Stat' je súčast'ou projektu Progres Q17 Příprava učitele a učitelské profese v kontextu vědy a výzkumu.

28 Samozrejme, uvedomujeme si, že čo sme uviedli, je iba náčrt rozkladu jediného symbolu. Keby sa podarilo celú algebraickú symboliku rozbit' na jej kognitívne komponenty, umožnilo by to presnejšie diagnostikovat' problémy žiakov pri úprave výrazov a pri slovných úlohách. Oddelený nácvik práce s jednotlivými komponentmi by potom mohol byt' cestou, ako tieto problémy účinne riešit'. 


\section{Literatúra}

Al-Chwárizmí, M. (1983). Kratkaja kniga ob isčislenii algebry i almukabaly [preklad z arabštiny B. A. Rozenfel'da]. In M. Al-Chorezmi, Matematičeskije traktaty (s. 20-81). Taškent: Izdatel'stvo FAN Uzbekskoj SSR.

Cardano, G. (1968). Ars magna, or the rules of algebra. Cambridge: MIT Press.

De Risi, V. (2016). The development of Euclidean axiomatics. Archive for History of Exact Sciences, 70(6), 591-676.

Dubinsky, E., \& Mcdonald, M. A. (2001). APOS: A constructivist theory of learning in undergraduate mathematics education research. In D. Holton et al. (Eds.), The teaching and learning of mathematics at university level [New ICMI Study Series, Vol. 7] (s. 273-280). Dordrecht: Springer.

Eukleides (2007). Základy, knihy I-IV [preklad F. Servíta komentovaný P. Vopěnkom]. Nymburk: OPS.

Frege, G. (1989). Funktion und Begriff. In: G. Frege, Funktion, Begriff, Bedeutung (s. 17-39). Göttingen: Vandenhoek \& Ruprecht.

Gray, J. (1989). Ideas of space, Euclidean, non-Euclidean and relativistic. Oxford: Clarendon Press.

Hejný, M. (2007). Budování matematických schémat. In A. Hošpesová et al. (Eds.), Cesty zdokonalování kultury vyučování matematice (s. 81-122). České Budějovice: Jihočeská univerzita.

Husserl, E. (1939). Die Frage nach dem Ursprung der Geometrie als intentionalhistorisches Problem. Revue Internationale de Philosophie, 1(2), s. 203-225.

Jirotková, D. (2017). Rytmus, pohyb, periodicita, nejmenší společný násobek dvou přirozených čísel. In: J. Slavík et al., Didaktické kazuistiky v oborech školního vzdělávání (s. 187-216). Brno: Masarykova univerzita.

Kohout, J., Mollerová, M., Masopust, P., Feřt, L., \& Slavík J. (2019). Kritická místa kurikula na základní škole pohledem mezinárodního šetření TIMSS a českých učitelů, poznatky z fyziky. Pedagogická orientace, 29(1), 5-42.

Kuhn, T. S. (1982). Štruktúra vedeckých revolúcií. Bratislava: Pravda.

Kvasz, L. (1995). On the significance of Piaget's concept of the epistemological framework for mathematics education. Acta Didactica Universitatis Comenianae, 4, 55-65.

Kvasz, L. (1996). Náčrt analytickej teórie subjektu. Filosofický časopis, 44(4), 617-640.

Kvasz, L. (1998a). O revolúciách vo vede a ruptúrach v jazyku vedy. Bratislava: Univerzita Komenského.

Kvasz, L. (1998b). History of geometry and the development of the form of its language. Synthese, 116(2), 141-186.

Kvasz, L. (1999). On classification of scientific revolutions. Journal for General Philosophy of Science, 30(2), 201-232.

Kvasz, L. (2000a). Changes of language in the development of mathematics. Philosophia mathematica, 8(1), 47-83.

Kvasz, L. (2000b). Epistemologické aspekty dejín klasickej algebry. Filozofia, 55(10), 788-808.

Kvasz, L. (2001a). Epistemologické aspekty dejín modernej algebry. Filozofia, 56(5), 309-331.

Kvasz, L. (2001b). O Piagetovi, dialektike a členskom. Organon F, 8(1), 56-73.

Kvasz, L. (2002). Galilean physics in light of Husserlian phenomenology. Philosophia Naturalis, 39(2), 209-233.

Kvasz, L. (2003). The mathematisation of nature and Cartesian physics. Philosophia Naturalis, 40(2), 157-182.

Kvasz, L. (2005a). Similarities and differences between the development of geometry and of algebra. In C. Cellucci \& D. Gillies (Eds.), Mathematical reasoning and heuristics (s. 25-47). London: King's College Publications.

Kvasz, L. (2005b). The mathematisation of nature and Newtonian physics. Philosophia Naturalis, 42(2), 183-211. 
32 Kvasz, L. (2006). History of algebra and the development of the form of its language. Philosophia Mathematica, 14(3), 287-317.

Kvasz, L. (2008a). Patterns of Change, Linguistic Innovations in the Development of Classical Mathematics. Basel: Birkhäuser.

Kvasz, L. (2008b). Sprache und Zeichen in der Geschichte der Algebra - ein Beitrag zur Theorie der Vergegenständlichung. Journal für Mathematik-Didaktik, 29(2), 108-123.

Kvasz, L. (2012a). Kuhnova Štruktúra vedeckých revolúcií medzi históriou a epistemológiou. Teorie vědy, 34(2), 167-187.

Kvasz, L. (2012b). Galileo, Descartes, and Newton - founders of the language of physics. Acta Physica Slovaca, 62(6), 519-614.

Kvasz, L. (2013a). Zrod vedy ako lingvistická udalost'. Galileo, Descartes a Newton ako tvorcovia jazyka fyziky. Praha: Filosofia.

Kvasz, L. (2013b). Jazyk matematiky, jeho změny a didaktika matematiky. Pokroky matematiky, fyziky a astronomie, 58(4), 315-325.

Kvasz, L. (2013c). Historické aspekty vyučování algebry. In M. Rendl et al., Kritická místa matematiky na základní škole očima učitelů (s. 301-324). Praha: Pedagogická fakulta UK.

Kvasz, L. (2014a). Thalétova matematika v zrkadle Galileovej fyziky. Filosofický časopis, 62(5), 643-659.

Kvasz, L. (2014b). Kuhn's Structure of Scientific Revolutions between sociology and epistemology. Studies in History and Philosophy of Science, 46(2), 78-84.

Kvasz, L. (2015a). Inštrumentálny realizmus. Praha: Pavel Mervart.

Kvasz, L. (2015b). Über die Konstitution der symbolischen Sprache der Mathematik. In G. Kadunz (Ed.), Semiotische Perspektiven auf das Lernen von Mathematik (s. 51-67). Berlin: Springer.

Kvasz, L. (2016). Princípy genetického konštruktivizmu. Orbis Scholae, 10(2), 15-45.

Kvasz, L. (2017). Pythagorejská matematika vo svetle karteziánskej fyziky. Filosofický časopis, 65(4), 513-541.

Kvasz, L. (2018). On the roles of language in mathematics education. In P. Ernest (Ed.), Philosophy of mathematics education today (s. 229-240). Cham: Springer.

Kvasz, L. (2020). Prostor mezi geometrií a malířstvím. Praha: Slovart.

Posner, J., Strike, K., Hewson, P., \& Gertzog, W. (1982). Accommodation of a scientific conception: Toward a theory of conceptual change. Science Education 66(2), 211-227.

Rodová, V., \& Slavík, J. (2018). Živé obrazy jako metoda výuky dějepisu: analytické zobecnění poznatků z praxe. Studia paedagogica, 23(3), 9-47.

Rusek, M., Slavík, J., \& Najvar, P. (2016). Obsahová konstrukce a didaktické uplatnění prírodovědného edukačního experimentu ve výuce na př́kladu chemie. Orbis Scholae, 10(2), 71-91.

Slavík, J. (2017). Kvaszův instrumentální realizmus v zorném poli didaktiky. Pedagogika, 67(3), 311-322.

Šír, Z. (Ed.). (2011). Řecké matematické texty. Praha: Oikoymenh.

Thagard, P. (1992). Conceptual revolutions. Princeton: Princeton University Press.

Vopěnka, P. (2003). Úhelný kámen evropské vzdělanosti a moci. Praha: Práh.

Wittgenstein, L. (1989). Tractatus Logico-philosophicus. Frankfurt am Main: Suhrkamp.

Prof. RNDr. Ladislav Kvasz, DSC. Katedra matematiky a didaktiky matematiky Pedagogická fakulta Univerzity Karlovy Magdalény Rettigové 4, 11639 Praha 1 ladislav.kvasz@pedf.cuni.cz 